\title{
Analisis Dinamika Permukaan Laut di Laut Jawa dengan Recurrent Neural Network Periode 1993 sampai 2019
}

\author{
Zamna Mujadida $^{1 *}$, Heryoso Setiyono ${ }^{1}$, Gentur Handoyo ${ }^{1}$, Hariyadi ${ }^{1}$ dan Jarot Marwoto ${ }^{1}$ \\ ${ }^{1}$ Departemen Oseanografi, Fakultas Perikanan dan Ilmu Kelautan, Universitas Diponegoro \\ Jl.Prof.H.Soedarto,SH., Tembalang, Semarang, 50275 Telp/Fax (024)7474698 \\ Email* : zamnamujadida@students.undip.ac.id
}

\begin{abstract}
Abstrak
Kenaikan muka air laut yang terjadi setiap tahun dapat disebabkan oleh perubahan iklim yang tidak stabil. Perubahan iklim tersebut disebabkan oleh meningkatnya suhu bumi yang merupakan dampak dari peningkatan gas rumah kaca. Kenaikan muka air laut dapat menyebabkan terganggunya aktivitas manusia terutama di daerah pesisir. Penelitian ini bertujuan menganalisis dinamika perubahan permukaan laut di Laut Jawa dan memprediksi data masa depan menggunakan pendekatan machine learning dengan arsitektur jaringan Recurrent Neural Network (RNN). Data utama yang digunakan adalah data sea level anomaly di Laut Jawa dari tahun 1993 sampai 2019 yang diterbitkan Copernicus Marine Environment Monitoring Service (CMEMS) didukung peta RBI Indonesia dan peta arus permukaan di Laut Jawa. Hasil analisis menunjukkan terjadinya peningkatan nilai muka air laut sejak tahun 1993 sekitar 37,545 mm/tahun. Tren kenaikan tercepat muka air laut di Laut Jawa mencapai nilai 72,313 mm pada tahun 2015-2016 sedangkan tren paling lambat terjadi pada tahun 2002-2005 sekitar 16,7 mm. Perubahan tren muka air laut yang ekstrim terjadi pada tahun 1996-1998 dan pada tahun 2010-2016 dikarenakan terjadinya fenomena El Nino dan La Nina. Evaluasi model dari RNN didapatkan nilai MSE sebesar 0,0000343, nilai RMSE 0,0058564, nilai $\mathrm{R}^{2}$ 0,993, dan nilai MAE 0,0045024. Hasil evaluasi tersebut menunjukkan nilai error yang sangat kecil sehingga dapat disimpulkan bahwa model RNN sangat akurat untuk memprediksi dinamika permukaan laut.
\end{abstract}

Kata kunci : Dinamika permukaan laut, Laut Jawa, Recurrent Neural Network

\begin{abstract}
The sea-level rise occurring every year is caused by unstable climate change. Whereas, climate change is caused by increasing earth temperature, which is the impact of increasing greenhouse gases. Sea level rise can disrupt human activities, especially in coastal areas. This study aims to analyze the dynamics of sea-level changes in the Java Sea and predict future data using a machine learning approach with a Recurrent Neural Network (RNN) architecture. The main data used is sea level anomaly data in the Copernicus Marine Environment Monitoring Service (CMEMS) supported by RBI maps of Indonesia and maps of surface currents in the Java Sea. The results of the analysis show that there has been an increase in sea level values since 1993 around 37,545 mm/year. The fastest rising trend in sea level in the Java Sea reached 72,313 mm in 2015-2016, while the slowest trend occurred in 2002-2005 around 16,7 mm. Changes in extreme sea level trends occurred in 1996-1998 and 2016 due to the occurrence of El Nino and La Nina phenomena. Evaluation of the model from the RNN obtained an MSE value of 0,0000343 , an RMSE value of 0,0058564, an $R^{2}$ value of 0,993, and an MAE value of 0,0045024. The evaluation shows a very small error value, so it can be concluded that the RNN model is very accurate for predicting sealevel dynamics.
\end{abstract}

Keywords : Sea Surface Dynamics, Java Sea, Recurrent Neural Network

\section{PENDAHULUAN}

Salah satu dampak dari pemanasan global adalah adanya perubahan iklim yang diakibatkan adanya peningkatan suhu bumi secara global dari tahun ke tahun yang disebabkan oleh efek rumah kaca atau greenhouse effect. Perubahan iklim dapat terjadi karena proses alam internal maupun faktor 
eksternal dari manusia yang menyebabkan perubahan pada komposisi atmosfer dan tata guna lahan. Dampak yang paling luas dari perubahan kondisi fisik atmosfer bumi dari suhu dan distribusi hujan serta mencairnya es di kutub adalah kenaikan muka air laut (sea level rise) (Khasanah dan Marza, 2017). Kenaikan muka air laut wilayah Indonesia berada pada kisaran 2,5 $\mathrm{mm}$ hingga $6 \mathrm{~mm}$ per tahun, pada tahun 2012 mencapai nilai 5,84 mm per tahun (Nababan, 2015). Menurut Kismawardhani et al. (2018), nilai ini hampir dua kali lipat lebih tinggi dari rata-rata kenaikan permukaan laut global. Hal ini tentunya berpengaruh besar pada pulau-pulau kecil di Indonesia. Dampaknya antara lain adalah mundurnya garis pantai ke arah darat, banjir di wilayah pesisir, mempercepat terjadinya erosi pantai berpasir, dan kerusakan infrastruktur yang berada di pantai seperti dermaga. Kehidupan masyarakat pesisir akan terganggu karena wilayahnya paling rentan terkena dampak kenaikan muka air laut. Salah satu perairan di Indonesia yang membawa efek besar ke banyak daratan adalah Laut Jawa, Laut Jawa merupakan perairan yang banyak berbatasan dengan pulau-pulau dan gugusan kepulauan di Indonesia. Fenomena oseanografi yang terjadi di Laut Jawa bervariasi karena mendapatkan pengaruh besar dari Samudera Hindia dan Samudera Pasifik.

Pemodelan dan prediksi dari perubahan kenaikan muka air laut membutuhkan data yang berkala dalam kurun waktu yang tidak singkat agar bisa memprediksikan hasilnya dengan akurat dan menganalisis tren yang terjadi dengan optimal. Penelitian ini mengaplikasi salah satu arsitektur machine learning tentang peramalan kenaikan muka air laut yang sudah banyak digunakan di berbagai bidang dan menghasilkan hasil yang baik, akan tetapi di bidang oseanografi cukup jarang digunakan yaitu menggunakan Recurrent Neural Network (RNN). Analisis menggunakan RNN berguna untuk menganalisis evolusi temporal dari ketinggian muka air laut. Di beberapa sumber, metode machine learning merupakan pendekatan terbaik untuk melakukan peramalan terhadap interannual sea level anomalies (SLA). Metode machine learning sangat bermanfaat untuk menganalisis data temporal yang jumlahnya sangat besar dan tergolong big data. Tujuan dari penelitian ini adalah menganalisis penyebab perubahan dinamika permukaan laut di Laut Jawa dari tahun 1993 sampai dengan tahun 2019 untuk dijadikan pembelajaran sehingga memungkinkan adanya penanganan dari dampak kenaikan muka air laut terutama pada daerah pesisir serta melihat efektivitas penggunaan machine learning untuk pemodelan dan prediksi muka air laut.

\section{MATERI DAN METODE PENELITIAN \\ Materi Penelitian}

Materi yang digunakan dalam penelitian ini adalah data sea level anomaly Laut Jawa dari tahun 1993 sampai 2019. Data utama yang digunakan adalah data satelit altimetri yang disediakan oleh Copernicus Marine Environment Monitoring Service (http://marine.copernicus.eu/) yaitu re-processing daily sea level anomalies (SLA). Data ini mengandung hasil dari data multi-mission satelit altimetri sejak Januari 1993 hingga Oktober 2019. Data sekunder yang digunakan adalah peta Rupa Bumi Indonesia yang disediakan oleh Badan Informasi Geospasial dan arus permukaan dari data satelit altimetri Jason-2.

\section{Metode Pengumpulan Data}

Data sea level anomaly dalam penelitian ini didapatkan dari data satelit altimetri yang disediakan oleh Copernicus Marine Environment Monitoring Service (CMEMS) yang dapat diunduh di laman http://marine.copernicus.eu/ yaitu re-processing daily sea level anomalies (SLA) level 4 maps yang disusun setiap tahun dengan resolusi spasial $0,25^{\circ} \times 0,25^{\circ}$ grid dengan format NetCDF (Network Common Data Form). Data dikumpulkan oleh satelit altimetri yang sudah direkam sejak 01 Januari 1993 sampai dengan 15 Oktober 2019 pada rentang wilayah $3^{\circ} 31^{\prime} 48^{\prime \prime} \mathrm{LS}-6^{\circ} 45^{\prime} 0^{\prime \prime} \mathrm{LS}$ dan $108^{\circ} 37^{\prime}$ 37,92 "BT - $110^{\circ} 25^{\prime} 22,8^{\prime \prime} \mathrm{BT}$ dengan 91 titik stasiun pengamatan. Lokasi stasiun pengamatan berada di tengah Laut Jawa untuk menghindari interaksi langsung dengan selat-selat yang berada di sekeliling Laut Jawa dan dipertimbangkan mampu menjadi gambaran dinamika permukaan laut di Laut Jawa. 


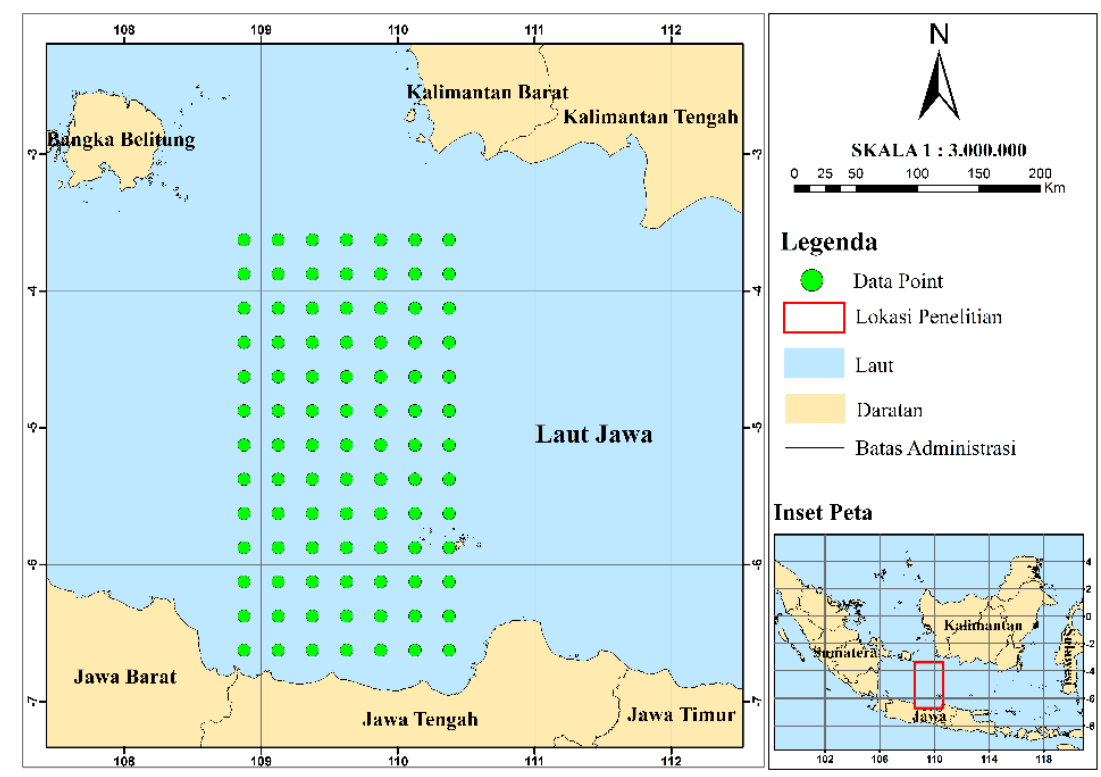

Gambar 1. Peta penelitian.

\section{Analisis dan Pengolahan Data Uji Kestasioneran Data}

Uji kestasioneran menggunakan data rata-rata bulanan karena tidak dimungkinkan menggunakan data harian dengan beban komputasi yang relatif besar, Pengujian dilakukan dengan metode uji Augmented Dickey-Fuller Test (ADF). Data time series dikatakan stasioner jika mean, variansi, dan kovariansinya konstan terhadap waktu. Jika tidak sesuai, maka data tersebut dikatakan tidak stasioner (Thomas, 1997).

\section{Prerepocessing}

Penelitian ini terdapat dua tahapan untuk preprocessing data yaitu splitting data dan normalisasi data. Pada tahapan splitting data, data dibagi menjadi data training dan testing. Rasio antara data training dan testing pada penelitian ini diambil 70\%. Dengan kata lain, data training diambil dari data SLA tahun 1993 sampai tahun 2011 digunakan untuk pemodelan. Setelah didapatkan model terbaik dari data training, model tersebut akan diuji pada data testing yaitu data SLA dari tahun 2012 sampai 2019 untuk melihat apakah model yang dihasilkan akan memiliki akurasi yang tinggi atau tidak. Pada tahap selanjutnya, data diubah menjadi bentuk supervised learning berdasarkan nilai dari look-back period. Look-back period adalah jumlah lag yang dilihat untuk memprediksi nilai pada waktu "t". Data time series dengan shape 1xn kemudian diubah menyesuaikan dengan kebutuhan tiap model.

\section{Inisialisasi hyperparameter model}

Hyperparameter merupakan salah satu faktor yang mempengaruhi kinerja dari model, untuk mendapatkan performa yang lebih tinggi saat melatih model tersebut. Ketika nilai hyperparameter diubah, kinerja model juga akan berubah. Inisialisasi hyperparameter pembelajaran meliputi learning rate yaitu $1 \mathrm{r}=0,001$, algoritma optimasi menggunakan ADAM, jumlah iterasi/epoch sebesar 300, dan batch size sebesar 100 .

\section{Fungsi Aktivasi dan Optimasi}

Fungsi aktivasi menggunakan ReLU yang merupakan fungsi aktivasi pada Artificial Neural Network yang saat ini banyak digunakan, berikut rumus pada ReLu.

$$
F(x)=\max (x, 0)
$$

Dimana $x$ merupakan input neuron yang dikenal sebagai fungsi ramp dan analog dengan rektifikasi halfwave pada teknik elektro. Jika input lebih besar 0 , outputnya sama dengan input. Optimasi menggunakan Adaptive Moment Estimation (ADAM). Metode ini menghitung tingkat pembelajaran adaptif individu 
untuk parameter yang berbeda dari perkiraan momen pertama dan kedua dari gradien. Pada Adam, learning rate beradaptasi berdasarkan parameter $\theta$. Perubahan learning rate dihitung dari estimasi momentum.

\section{Training Model}

Proses training digunakan untuk memperoleh bobot (weight) yang nantinya akan dijadikan model pada proses testing. Model akan mencoba mempelajari pola yang ada pada data latih dan melakukan pada setiap akhir epoch. Proses training akan dihentikan ketika nilai mean square error memenuhi target atau iterasi maksimal yang telah ditetapkan (Maharani, 2009). Dalam proses training, epoch dan batch size harus didefinisikan. Semakin banyak epoch maka semakin lama juga waktu yang dibutuhkan untuk training model. Dalam pelatihan model pembelajaran mesin di penelitian ini digunakan nilai mean absolute error (MAE).

\section{Verifikasi Model}

Verifikasi model pada penelitian ini adalah menggunakan tig a metode verifikasi data, yaitu Mean Squared Error (MSE), Root Mean Squared Error (RMSE), Mean Absolute Error (MAE).

Keterangan :

$$
\operatorname{MSE}=\frac{1}{n} \sum_{i=1}^{n}\left(y_{i}-\tilde{y}_{i}\right)^{2}
$$

$\mathrm{n}=$ Jumlah data

yi $=$ Nilai observasi

$\tilde{y} \mathrm{i}=$ Nilai prediksi

Keterangan:

$$
\begin{array}{ll}
\text { Xobs }, i & =\text { nilai observasi } \\
\text { Xmodel }, i & =\text { nilai model } \\
n & =\text { banyaknya populasi }
\end{array}
$$

$$
R M S E=\sqrt{\frac{\sum_{i=1}^{n}\left(x_{o b x, i}-x_{m o d e l, i}\right)^{2}}{n}}
$$

Keterangan

$$
\mathrm{MAE}=\frac{1}{n} \sum_{i=1}^{n}\left|x_{i}-x\right|
$$

$\mathrm{n}$ = Jumlah data

$\mathrm{xi}=$ Nilai hasil peramalan

$\mathrm{x}=$ Nilai sebenarnya

\section{HASIL DAN PEMBAHASAN}

\section{Hasil Uji Kestasioneran Data}

Hasil uji kestasioneran data menggunakan metode uji Augmented Dickey-Fuller Test (ADF) didapatkan hasil skor |ADF| statistiknya sebesar -2,509188 dengan nilai $p$ adalah 0,113255. Berdasarkan nilai p-value maka dapat disimpulkan data sea level anomaly di Laut Jawa selama tahun 1993-2019 adalah tidak stasioner karena nilai $\mathrm{p}$ lebih dari 0,05 sehingga hipotesis $\mathrm{H}_{\mathrm{o}}$ tidak tertolak, karena data yang digunakan tidak stasioner maka prediksi sea level anomaly tidak dapat menggunakan metode linear sederhana.

\section{Transformasi Data}

Transformasi data tabel menggunakan pustaka kode pandas dan komputasi menggunakan bahasa pemrograman Python 3.8. Nilai rata-rata sea level anomaly di Laut Jawa selama 1993-2019 diketahui adalah sebesar $0,037545 \mathrm{~m}$, dengan nilai minimum di angka $-0,217 \mathrm{~m}$ dan nilai maksimum di angka $0,343 \mathrm{~m}$. Data ini memiliki standar deviasi 0,07001. 


\section{Variasi Spasial Kenaikan Muka Air Laut Laut Jawa Tahun 1993-2019}

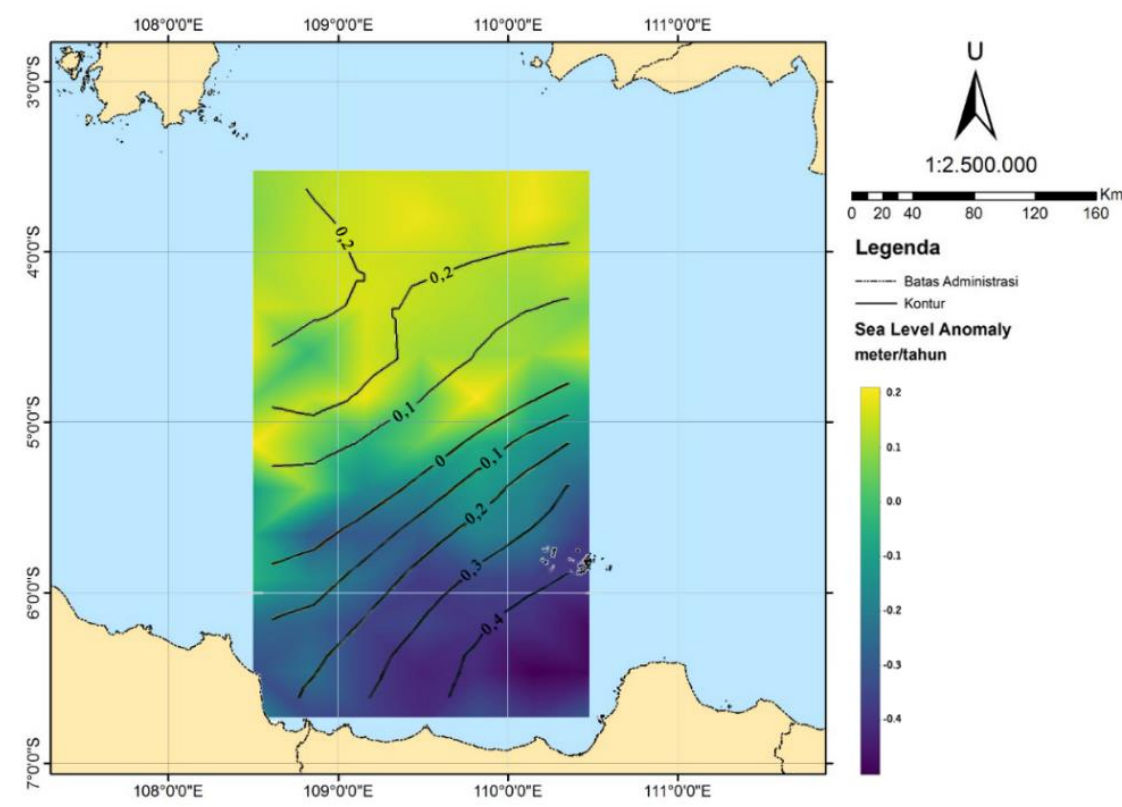

Gambar 2. Variasi spasial SLA Laut Jawa tahun 1993-2019 pada 91 titik stasiun pengamatan

Pada wilayah $108^{\circ} 47^{\prime} 60^{\prime \prime B T}-110^{\circ} 24^{\prime} 0^{\prime \prime B T}$ pada lintang $6^{\circ} 30^{\prime} 0^{\prime \prime} \mathrm{LS}$ menunjukkan perubahan indeks warna dari warna ungu ke warna biru, rentang wilayah tersebut merupakan daerah yang lebih dekat dengan pesisir yaitu bagian Utara Pulau Jawa yang menunjukkan nilai anomali paras laut yang rendah selama tahun 1993 - 2019 nilainya berada di rentang -0,25 sampai -0,34 m/tahun. Pada wilayah di rentang $110^{\circ} 12^{\prime} 0^{\prime \prime} B T-110^{\circ} 24^{\prime} 0 " B T$ pada lokasi lintang yang masih sama yaitu $6^{\circ} 30^{\prime} 0^{\prime \prime} L S$ terlihat warna ungu lebih pekat daripada pada rentang wilayah $108^{\circ} 47^{\prime} 60^{\prime \prime B T ~-~} 110^{\circ} 12^{\prime} 0^{\prime \prime} \mathrm{BT}$, hal ini menandakan variasi nilai SLA yang paling rendah yaitu $-0,34 \mathrm{~m} /$ tahun. Sementara pada rentang wilayah $5^{\circ} 0^{\prime} 0^{\prime \prime} \mathrm{LS}-5^{\circ} 30^{\prime} 0 " \mathrm{LS}$ dan $108^{\circ} 47^{\prime} 60^{\prime \prime} \mathrm{BT}-110^{\circ} 24^{\prime} 0^{\prime \prime} \mathrm{BT}$ variasi SLA dominan warna biru sampai warna hijau dengan rentang nilai SLA 0 sampai $-0,20 \mathrm{~m} /$ tahun, sedangkan di rentang wilayah lintang yang sama dengan rentang bujur $109^{\circ} 0^{\prime} 0$ "BT sampai $109^{\circ} 12^{\prime} 0^{\prime \prime} \mathrm{BT}$ terlihat sedikit warna kuning yang menandakan nilai anomali mulai meningkat dengan nilai sebesar $0,2 \mathrm{~mm} / \mathrm{tahun}$. Pada rentang wilayah di $3^{\circ} 42^{\prime} 0^{\prime \prime} \mathrm{LS}$ sampai $4^{\circ} 30^{\prime} 0^{\prime \prime} \mathrm{LS}$ dan $108^{\circ} 47^{\prime} 60^{\prime \prime} \mathrm{BT}$ sampai $110^{\circ} 24^{\prime} 0^{\prime \prime} \mathrm{BT}$ indeks warna yang dominan adalah warna hijau kekuningan dan kuning yang menandakan nilai anomali semakin tinggi dengan nilai 0,1 sampai $0,20 \mathrm{~m} /$ tahun. Wilayah dengan rentang $3^{\circ} 42^{\prime} 0^{\prime \prime} \mathrm{LS}-4^{\circ} 30^{\prime} 0^{\prime \prime} \mathrm{LS}$ dan $109^{\circ} 24^{\prime} 0^{\prime \prime} \mathrm{BT}$ $110^{\circ} 12^{\prime} 0^{\prime \prime} \mathrm{BT}$ memperlihatkan warna kuning yang mendominasi menunjukkan wilayah tersebut memiliki nilai anomali yang paling tinggi yaitu $0,20-0,3 \mathrm{~m} /$ tahun.

\section{Variasi Temporal Muka Air Laut Laut Jawa Tahun 1993-2019}

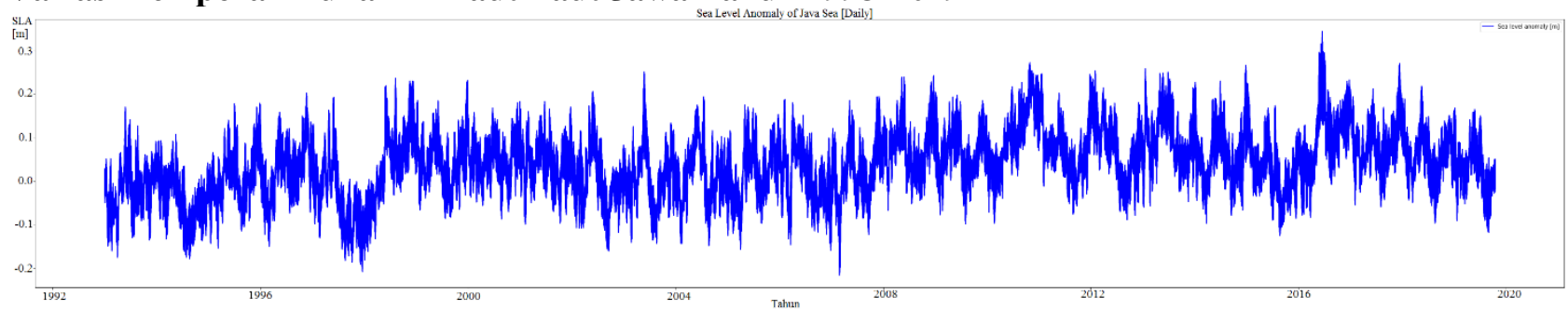

Gambar 3. Variasi temporal SLA rata-rata harian Laut Jawa tahun 1993-2019 pada 91 titik stasiun pengamatan. 


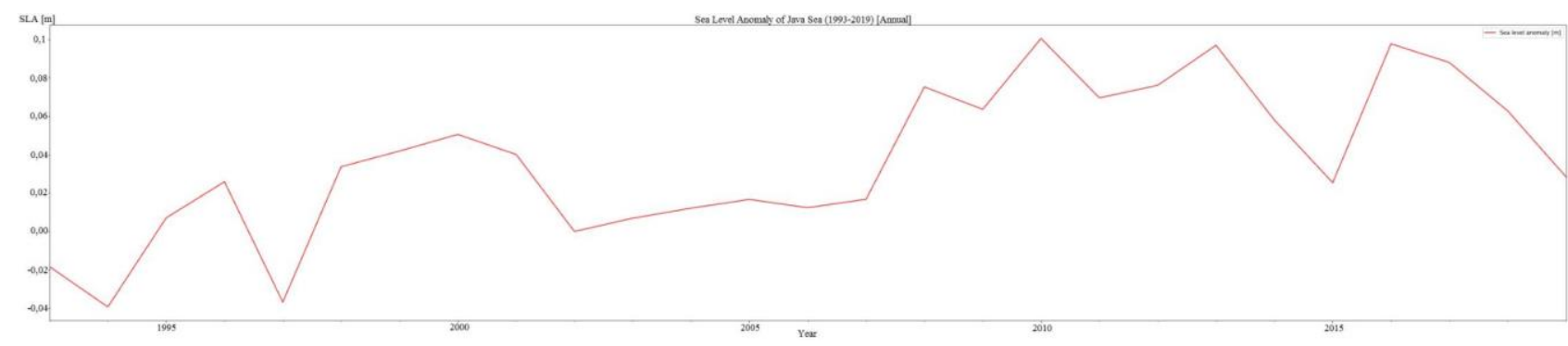

Gambar 4. Variasi temporal SLA rata-rata tahunan Laut Jawa tahun 1993-2019 pada 91 titik stasiun pengamatan.

Tren kenaikan tercepat muka air laut di Laut Jawa mencapai nilai 0,072313 m pada tahun 20152016 sedangkan tren paling lambat terjadi pada tahun $2002-2005$ sekitar $16,7 \mathrm{~mm}$.

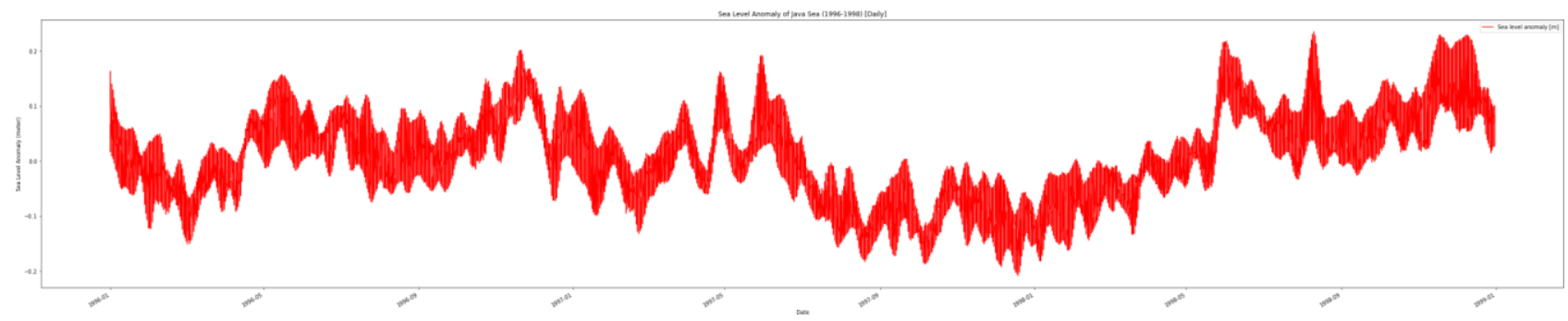

Gambar 5. Variasi temporal SLA rata-rata harian Laut Jawa tahun 1996-1998 pada 91 titik stasiun pengamatan.

Nilai tren pada tahun 1997 turun dari 25,875 mm menjadi -36,849 mm. Artinya terjadi penurunan nilai trend sekitar 0,062724 m atau $63 \mathrm{~mm}$ pada periode 1996 hingga 1997 dan naik nilainya sekitar 0,07054 m atau $71 \mathrm{~mm}$ pada periode 1997 hingga 1998 dimana pada tahun 1998 nilai kenaikan muka air laut naik kembali menjadi $33,691 \mathrm{~mm}$. Keduanya menunjukkan tren perubahan permukaan laut yang ekstrim yang terjadi pada periode 1996 hingga 1998.

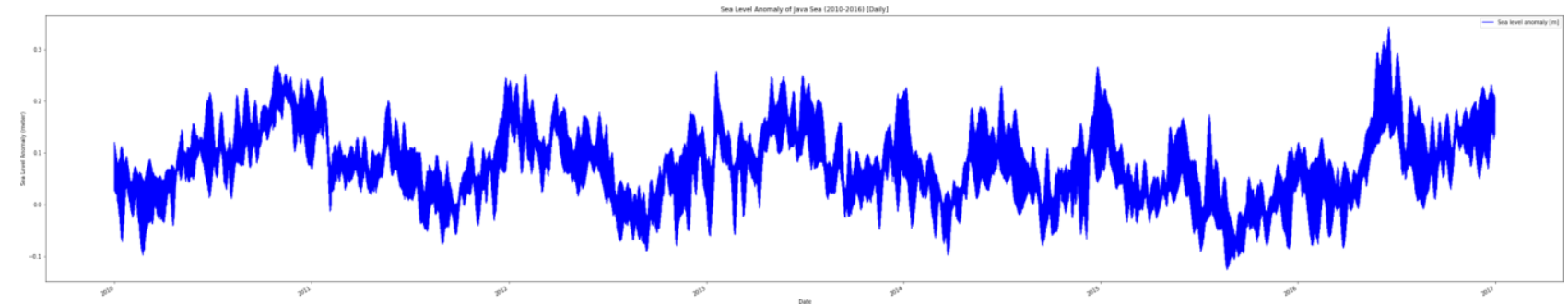

Gambar 6. Variasi temporal SLA rata-rata harian Laut Jawa tahun 2010-2016 pada 91 titik stasiun pengamatan.

Kenaikan muka air laut yang ekstrim selanjutnya terjadi pada rentang tahun 2010 sampai tahun 2016, dimana terjadi tren penurunan muka air laut pada tahun 2010 sampai 2015 yaitu sebesar 75,12 mm kemudian naik pada tahun 2016 sehingga tren muka air laut mengalami kenaikan sebesar 72,313 $\mathrm{mm}$.

\section{Prediksi Kenaikan Muka Air Laut Laut Jawa sampai tahun 2036}

Hasil prediksi SLA tahun 2019 hingga 2036 menunjukkan nilai SLA hampir stasioner karena perubahan yang terjadi terlihat konstan, perbedaan tren kenaikan dan penurunannya sangat kecil. Pada tahun 2019 - 2026 mengalami tren kenaikan, kemudian turun hingga tahun 2030. Nilai tertinggi yang didapatkan dari hasil prediksi selama periode tersebut terjadi pada tahun 2032 dengan nilai SLA 0,152 $\mathrm{m}$ dan nilai SLA terendah adalah $-0,0394 \mathrm{~m}$ yang terjadi pada tahun 2035 . Pada dekade pertama (periode 
2019 - 2029) jarang terjadi penurunan nilai SLA secara signifikan, nilai minus terjadi hanya pada tahun 2028 dan 2029. Berbeda dengan periode selanjutnya (tahun 2030 - 2036) dimana terjadi cukup besar perubahan muka air laut yaitu dari nilai $0,093 \mathrm{~m}$ menjadi $0,1517 \mathrm{~m}$ turun lagi menjadi $0,05 \mathrm{~m}$.

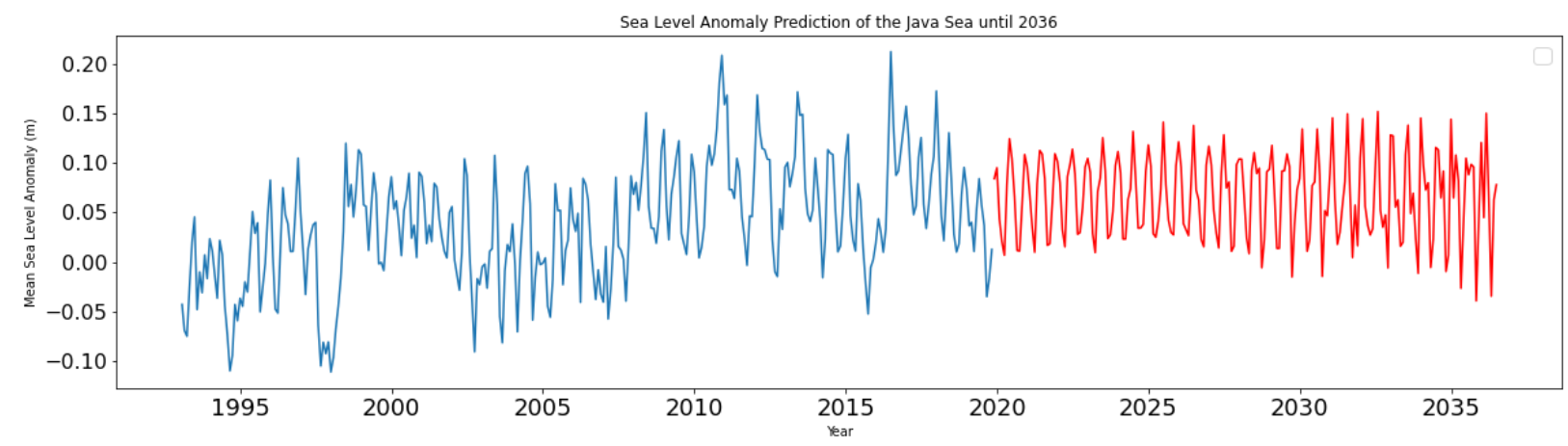

Gambar 7. Prediksi SLA di Laut Jawa tahun sampai tahun 2036 pada koordinat $3^{\circ} 31^{\prime} 48^{\prime \prime L S ~-~}$ $6^{\circ} 45^{\prime} 0^{\prime \prime} \mathrm{LS}$ dan $108^{\circ} 37^{\prime} 37.92^{\prime \prime} \mathrm{BT}-110^{\circ} 25^{\prime} 22.8^{\prime \prime} \mathrm{BT}$

\section{Evaluasi Metode Recurrent Neural Network (RNN)}

Berdasarkan pelatihan didapatkan nilai waktu yang digunakan untuk model RNN belajar pada data training adalah 12,142 menit dengan nilai loss model secara umum sebesar 0,0045 atau 0,45\%. Nilai loss model di akhir pelatihan adalah sebesar 0,0044 training loss dan 0,0047 validation loss.

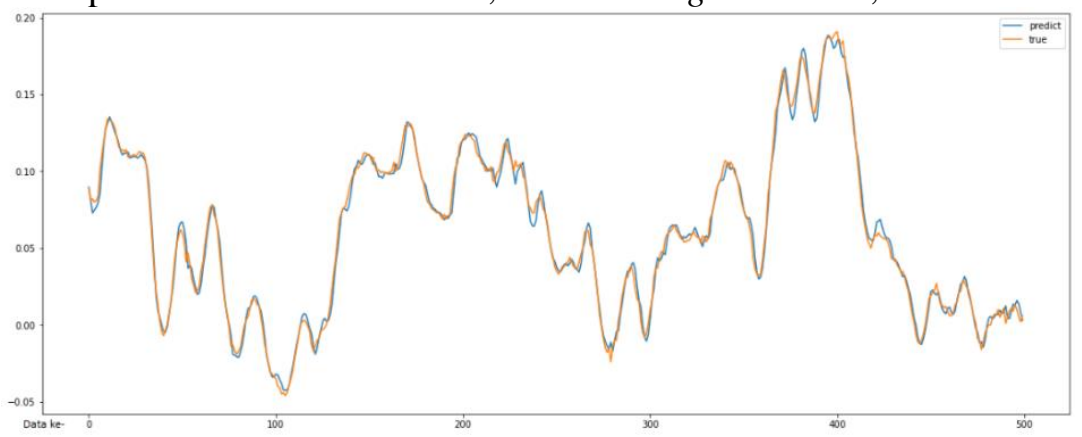

Gambar 8. Hasil prediksi model RNN pada 500 data pertama data testing.

Dari grafik cukup bisa diinterpretasikan bahwa prediksi sudah cukup akurat dengan pola grafik prediksi yang selalu mendekati pola data sebenarnya. Dari evaluasi didapatkan nilai MSE sebesar 0,0000343, nilai RMSE 0,0058564, nilai $\mathrm{R}^{2}$ 0,993, dan nilai MAE 0,0045024.

\section{Pembahasan}

Laut Jawa secara spasial mengalami kenaikan muka air laut. Pola tren kenaikan muka air laut di Laut Jawa secara spasial dapat dilihat pada Gambar 2 dimana indeks warnanya menunjukkan semakin ke Utara nilainya di Laut Jawa semakin besar. Pada wilayah Selatan lebih dekat dengan pesisir Utara Pulau Jawa yang menunjukkan nilai kenaikan muka air laut berada di antara rentang $-0,1 \mathrm{~m} /$ tahun sampai $-0,37 \mathrm{~m} / \mathrm{tahun}$, semakin menuju ke arah utara atau arah laut lepas nilainya semakin besar berada di antara rentang $0 \mathrm{~m} /$ tahun sampai $0,2 \mathrm{~m} /$ tahun. Apabila dilihat secara melintang dari Timur ke Barat pada wilayah bagian Selatan nilai muka air laut mengalami kenaikan dilihat dari gradasi warna dari ungu ke biru, sedangkan pada wilayah Utara dominan berwarna hijau kekuning-kuningan yang menunjukkan tingginya nilai kenaikan muka air laut di wilayah tersebut. Hal ini dapat diakibatkan oleh pergerakan arus di Indonesia dimana setiap Bulan Oktober sampai Bulan April arus bergerak dari arah Benua Asia menuju ke Benua Australia dikarenakan adanya angin Muson Barat saat angin bertiup dari Barat menuju Timur (Daruwedho et al., 2016). Wyrtki (1961) menjelaskan, Di Perairan Laut Jawa, pada Musim Barat angin bergerak dari arah Barat ke arah Timur, sedang pada Musim Timur bergerak dari arah Timur ke arah Barat. Hal ini menyebabkan adanya pengumpulan massa air di bagian Barat Laut Laut Jawa karena arus yang masuk ke Laut Jawa menyebabkan tren kenaikan muka air laut di daerah 
tersebut selalu tinggi. Arus yang menuju arah Tenggara akan menyebar yang menyebabkan penurunan massa air di daerah tersebut. Pada saat Muson Timur arus akan bergerak dari Benua Australia menuju Benua Asia, dikarenakan adanya angin Muson Timur saat angin bertiup dari arah Timur ke arah Barat (Daruwedho et al., 2016). Hal ini menyebabkan pengumpulan massa air juga di daerah Barat Laut Laut Jawa karena arus laut dari Timur Indonesia sebagian besar menuju bagian Barat Laut Laut Jawa. Penelitian Kismawardhani et al. (2018) juga menunjukkan adanya kenaikan anomali muka air laut dari bagian Timur ke bagian Barat Laut Jawa. Saat tahun kejadian El Niño (1997) pada Musim Barat (Februari) dan Musim Peralihan (Mei dan November) arus mengalir dari Samudera Hindia ke Laut Jawa, sedangkan pada Musim Timur (Agustus) arus bergerak sebaliknya. Pada bulan Agustus terjadi aliran maksimum ke Samudera Hindia dan pada bulan Juni terjadi aliran maksimum ke Laut Jawa. Pada tahun La Niña, pergerakan arus umumnya akan menuju Laut Jawa, kecuali pada bulan Agustus (Musim Timur) dan bulan Oktober (Musim Peralihan) arus akan bergerak menuju Samudera Hindia (Jumarang et al., 2019).

Tren kenaikan muka air laut di Laut Jawa dapat dilihat pada Gambar 3 dan 4 menunjukkan adanya peningkatan nilai sejak tahun 1993 sekitar 37,545 mm per tahun. Naik dan turunnya permukaan laut yang terjadi di Laut Jawa dapat terjadi karena adanya transpor massa, salah satunya saat terjadi angin muson. Setiap Bulan Oktober sampai Bulan April arus bergerak dari arah Benua Asia menuju ke Benua Australia dikarenakan adanya angin Muson Barat saat angin bertiup dari Barat menuju Timur (Daruwedho et al., 2016). Wyrtki (1961) menjelaskan, Di Perairan Laut Jawa, pada Musim Barat angin bergerak dari arah Barat ke arah Timur, sedang pada Musim Timur bulan Juni sampai Agustus arus bergerak dari arah Timur ke arah Barat. Pada saat ini akan terjadi transpor massa masuk ke Laut Jawa atau ke luar Laut Jawa. Saat massa air masuk ke Laut Jawa akan menaikkan volume air laut sehingga permukaan laut akan naik, sedangkan saat massa air keluar Laut Jawa akan terjadi penurunan permukaan laut. Faktor lain yang dapat mempengaruhi dinamika permukaan laut adalah iklim, jumlah masukan air ke laut saat musim kemarau dan hujan pasti akan berbeda dimana curah hujan berpengaruh pada kenaikan permukaan laut. Faktor yang mempengaruhi curah hujan adalah suhu permukaan laut yang kenaikannya dapat diakibatkan oleh pemanasan global. Menurut Wyrtki (1961), limpasan air yang datang dari sungai akibat dari besarnya curah hujan akan mempengaruhi kenaikan muka air laut akibat adanya masukan air dari daratan. Rata-rata curah hujan tahunan pada Kota Semarang berdasarkan data Bappeda pada stasiun Tanjung Mas pada tahun 2014 adalah 207 mm sedangkan di stasiun Karang Tengah memiliki rata-rata curah hujan tahunan $166 \mathrm{~mm}$. Berbanding terbalik dengan suhu udara yang mengalami kenaikan setiap tahunnya, curah hujan di stasiun Semarang menurut data Bappeda pada tahun 2018 mengalami penurunan rata-rata tahunannya menjadi $164 \mathrm{~mm}$. Walaupun begitu efek dari perubahan iklim yang ekstrem mengakibatkan terjadinya fenomena El Niño dan La Niña yang akan berpengaruh pada curah hujan dan kenaikan muka air laut.

Gambar 3 dan 4 menunjukkan bahwa setiap tahun sejak tahun 1993 Laut Jawa selalu mengalami kenaikan permukaan laut. Faktor-faktor yang dapat menyebabkan terjadinya kenaikan muka air laut setiap tahun ini adalah adanya peningkatan suhu global yang meningkatkan pemuaian air laut dan adanya pencairan gletser di Greenland dan Antartika yang meningkatkan volume air laut (Strassburg $e t$ al., 2015). Berdasarkan laporan IPCC (2007), suhu udara di bumi selalu mengalami kenaikan sebesar $0.3^{\circ} \mathrm{C}-1^{\circ} \mathrm{C}$ per tahunnya dikarenakan adanya kenaikan gas $\mathrm{CO}_{2}$ yang akan memberikan dampak besar pada efek rumah kaca. Salah satu kota yang dekat dengan stasiun pengamatan adalah Kota Semarang, kenaikan suhu udara di Kota Semarang sebesar $0.0257^{\circ} \mathrm{C} /$ tahun yang artinya kenaikan suhunya lebih besar daripada kenaikan rata-rata suhu permukaan wilayah daratan Indonesia yaitu sebesar $0,016^{\circ} \mathrm{C} /$ tahun (Bappenas, 2014). Kenaikan suhu udara secara global membuat muka air laut ikut naik, dimana setiap $1^{\circ} \mathrm{C}$ kenaikan suhu udara menyebabkan muka air laut naik 2,3 meter dalam kurun waktu dua ribu tahun mendatang (Levermann et al., 2013). Penelitian tersebut mendukung pendapat Rahmstoff et al. (2012) yang mengatakan adanya kenaikan muka air laut sebesar $3,2 \mathrm{~mm} /$ tahun dari $2 \mathrm{~mm} /$ tahun yang pernah dikemukakan IPCC (2007), kenaikan ini diakibatkan adanya perubahan iklim yang terjadi setelah tahun 2010. Bumi ini perlu waktu untuk mengalami penghangatan dan menahan kenaikan suhu tersebut dalam kurun waktu yang cukup lama (Levermann et al., 2013). Sehingga dapat diketahui bahwa kenaikan suhu udara memberikan dampak jangka panjang terhadap kenaikan muka air laut. Kenaikan 
suhu udara sejalan dengan kenaikan suhu permukaan laut, kenaikan suhu akan menyebabkan terjadinya fenomena lain secara jangka pendek yang akan mempengaruhi kenaikan muka air laut, fenomena tersebut antara lain curah hujan, IOD, serta peristiwa El Niño dan La Niña yang juga akan mempengaruhi besarnya curah hujan.

Tren muka air laut yang ekstrim pada rentang waktu 1996-1998 ditunjukkan gambar 5 dan 20102016 pada gambar 6 dapat terjadi karena adanya peristiwa El Niño di tahun 1997 dan 2015 dan La Niña pada tahun 2010/2011. Khasanah et al. (2017) mengatakan kenaikan permukaan laut juga dipengaruhi oleh La Niña dan El Niño, El Niño menyebabkan permukaan laut turun. Pada saat yang sama, La Niña menyebabkan permukaan laut naik. Pada penelitian Nabilah et al. (2017) untuk melihat pengaruh dari perubahan suhu permukaan laut di Laut Jawa terhadap intensitas curah hujan menunjukkan pada tahun terjadi La Niña saat Bulan Januari sampai Juni curah hujan berada di bawah curah hujan klimatologi sedangkan Bulan Juli sampai November nilainya di atas curah hujan klimatologi. Hal ini berlawanan pada tahun terjadi El Niño dimana pada Bulan Januari sampai Juni curah hujan berada di atas curah hujan klimatologi sedangkan Bulan Juli sampai November nilainya di bawah curah hujan klimatologi.

Pengaruh ENSO yang mengakibatkan terjadinya El Niño menurunkan muka air di Laut Jawa pada tahun 1997 (Idris, 2002), dimana pada saat El Niño pergerakan arus dari Samudera Pasifik bagian Barat ke Timur mengakibatkan elevasi muka laut di Samudera Pasifik bagian Barat dan Perairan Indonesia akan menurun. Hal tersebut menyebabkan adanya peningkatan transpor volume ke arah Laut Jawa pada tahun 1997 akibat adanya anomali SPL yang terjadi karena El Niño yang juga menyebababkan transpor volume ke Samudera Hindia berkurang (Jumarang et al., 2013). Sedangkan pada tahun 2015, terjadi gejala alam Super El Niño atau NASA menyebutnya "Godzilla El Niño" yang berdampak pada penurunan drastis nilai kenaikan muka air laut rata-rata pada bulan Juli 2015, fenomena yang terjadi di Samudera Pasifik ini membawa dampak pada permukaan laut Laut Jawa (Ginanjar et al., 2019). Wuriatmo (2012) menunjukkan bahwa selama periode 2010/2011 telah terjadi peningkatan kenaikan muka laut di Laut Jawa karena adanya fenomena La Niña yang meningkatkan suhu muka laut di Samudera Pasifik yang memicu terjadinya peningkatan laju anomali muka laut di Laut Indonesia (dalam hal ini Laut Jawa) sebagai akibat dari distribusi massa air dingin dari Samudera pasifik menuju Samudera Hindia. Hal ini sejalan dengan Kismawardhani et al. (2018) yang menunjukkan adanya keterkaitan antara SST (sea surface temperature) terhadap SLA di Laut Jawa dimana dengan meningkatnya SST selama periode 1993-2015 terjadi pula peningkatan SLA di Laut Jawa. Penelitian Oktaviani et al. (2014) juga menunjukkan pada bulan Juli 2010 terjadi elevasi rata-rata muka air laut tertinggi sepanjang tahun di Laut Jawa yang mencapai nilai 0,002572 meter akibat fenomena La Niña yang terjadi di tahun tersebut.

Kenaikan tinggi muka air laut pada saat masa transisi antara El Niño dan La Niña diantara tahun 2011-2015 disebabkan karena trade wind di Samudera Pasifik menguat dan membawa massa air dari Pasifik Timur di sekitar Peru ke daerah Perairan Indonesia, yang ditandai dengan perpindahan kolam air hangat (warm pool) dari Pasifik Tengah ke Laut Indonesia. Hal ini, menyebabkan naiknya gradien tinggi muka air laut, sehingga tinggi muka air laut di Laut Indonesia, $1 \mathrm{~m}$ lebih tinggi dibandingkan dengan tinggi muka air laut di sekitar Peru. Meskipun, angin lokal cenderung angin baratan karena turunnya tekanan udara di Darwin dan Perairan Indonesia yang berusaha menurunkan tinggi muka laut di Perairan Indonesia (Sofian, 2007).

IOD juga mempengaruhi kenaikan permukaan laut. Pada dasarnya jika permukaan laut naik sangat tinggi, IOD- dan La Niña dominan, tetapi jika kenaikan permukaan laut tidak besar, maka IOD+ dan ENSO lebih dominan. Indonesia yang termasuk dalam benua maritim juga mengalami peristiwa Madden Julian Oscillation (MJO). Fenomena ini berkaitan langsung dengan terbentuknya kolom air hangat di bagian Timur Samudera Hindia dan bagian Barat Samudera Pasifik, sehingga pergerakan MJO ke arah Timur bersama dengan angin Barat sepanjang ekuator selalu disertai dengan konveksi awan kumulus yang tebal yang menyebabkan curah hujan intensitas tinggi menyebar di sepanjang garis tersebut (Evana et al., 2008).

Prediksi sea level anomaly di Laut Jawa menggunakan model RNN (Recurrent Neural Network) didapatkan hasil grafik sea level anomaly yang terlihat pada Gambar 4. Pada penelitian ini waktu prediksi adalah dari November 2019 hingga Juni 2036. Berdasarkan Susanto et al. (2010), sebelum tahun 
2050 adalah kurun waktu yang dianggap signifikan terhadap kenaikan muka laut, sedangkan kurun setelah itu sebagian besar ahli belum memberikan penyataan secara pasti. Keakuratan hasil prediksi disajikan dalam Gambar 5 dan dihitung nilai evaluasi modelnya menggunakan empat indikator evaluasi yaitu MSE, RMSE, MAE, dan $\mathrm{R}^{2}$ yang dapat dihitung langsung oleh RNN. Dimana hasil evaluasinya adalah nilai MSE sebesar 0,0000343, nilai RMSE 0,0058564, dan nilai MAE 0,0045024. Hasil evaluasinya dari nilai MSE, RMSE, dan MAE menunjukkan bahwa tingkat error yang dihasilkan oleh model sangat kecil sehingga sangat akurat untuk digunakan memprediksi sea level anomaly. Model yang dihasilkan dengan menggunakan machine learning ini lebih akurat dibandingkan menggunakan metode regresi biasa. Ginanjar et al. (2019) memodelkan prediksi kenaikan muka air laut di kota Saumlaki pada tahun 2023, 2028, dan 2033 dengan metode regresi linear, didapatkan nilai $\mathrm{R}^{2}$ sebesar 0,7603. Sedangkan, nilai $\mathrm{R}^{2}$ dengan menggunakan RNN menghasilkan nilai sebesar 0,993. Hasil R-squared yang didapatkan dari model RNN memiliki nilai R-squared mendekati satu yang menandakan model tersebut sudah sangat baik untuk menganalisis dan memprediksi kenaikan muka air laut di Laut Jawa.

Data SLA merupakan data yang bervariasi dan tidak stasioner karena dapat dipengaruhi oleh banyak faktor yang terkadang sulit didefinisi, semakin banyak data yang digunakan akan semakin terlihat tren SLA yang terjadi dan semakin akurat pemodelannya. RNN berpedoman pada input data secara sekuensial atau berurutan dan sel memorinya yang dapat menangkap informasi tentang urutan panjang pada data time series kemungkinan besar mempengaruhi keakuratan dari model ini. Data SLA harus dianalisa dalam kurun waktu yang lama dikarenakan fenomenanya terjadi secara lambat tetapi setiap tahunnya masih dipengaruhi oleh fenomena-fenomena yang terjadi di lautan ataupun daratan yang sangat berpengaruh pada anomali muka air laut. Hal ini sesuai dengan sistem pemrosesan dari RNN.

Hasil prediksi menunjukkan tren kenaikan sea level anomaly di Laut Jawa sampai dengan tahun 2036 walaupun terjadi tren penurunan pada rentang tahun 2026-2030 tetapi mengalami kenaikan nilai SLA yang siginifikan lagi hingga tahun 2036. Nilai tertinggi yang didapatkan dari hasil prediksi selama periode tersebut terjadi pada tahun 2032 dengan nilai SLA 0,152 m dan nilai SLA terendah adalah $0.0394 \mathrm{~m}$ yang terjadi pada tahun 2035. Kenaikan muka air laut pada prediksi dapat terjadinya karena adanya kenaikan suhu global secara terus menerus yang dapat mengakibatkan semakin tingginya ekspansi termal, selain itu dapat menyebabkan tingkat pencairan gletser di kutub semakin membesar yang akan menambah volume massa air laut. Rahmstorf et al. (2012) mengatakan bahwa permukaan air laut di dunia sejak tahun 2010 mulai naik sekitar 3,2 mm/tahun dari $2 \mathrm{~mm} /$ tahun yang diakibatkan adanya perubahan iklim yang menyebabkan gletser dan bongkahan es di berbagai wilayah mencair, serta adanya peningkatan suhu air yang dapat mempengaruhi induksi massa dan ekspansi termal sebagai faktor terbesar terjadinya kenaikan muka air laut.

\section{KESIMPULAN}

Hasil analisis menunjukkan terjadinya peningkatan nilai muka air laut sejak tahun 1993 sekitar $37,545 \mathrm{~mm} / \mathrm{tahun}$. Tren kenaikan tercepat muka air laut di Laut Jawa mencapai nilai 72,313 $\mathrm{mm}$ pada tahun 2015-2016 sedangkan tren paling lambat terjadi pada tahun 2002-2005 sekitar 16,7 mm. Perubahan tren muka air laut yang ekstrim terjadi pada tahun 1996-1998 dan pada tahun 2010-2016 dikarenakan terjadinya fenomena El Nino dan La Nina. Evaluasi model dari RNN didapatkan nilai MSE sebesar 0,0000343, nilai RMSE 0,0058564, nilai $\mathrm{R}^{2}$ 0,993, dan nilai MAE 0,0045024. Hasil evaluasi tersebut menunjukkan nilai error yang sangat kecil sehingga dapat disimpulkan bahwa model RNN sangat akurat untuk memprediksi dinamika permukaan laut.

\section{DAFTAR PUSTAKA}

Daruwedho, Haryo., B. Sasmito, F. Janu. 2016. Analisis Pola Arus Laut Permukaan Perairan Indonesia dengan Menggunakan Satelit Altimetri Jason-2 Tahun 2010-2014. Jurnal Geodesi Undip. 5(2).

Evana, L., S. Effendy dan E. Hermawan. 2008. Pengembangan Model Prediksi Madden Julian Oscillation (MJO) Berbasis pada Hasil Analisis Data Real Time Multivariate MJO (RMM1 dan RMM2). J. Agromet, 22(2): 144-159.

Fausett, L. 1994. Fundamentals of Neural Network (Archetectures, Algorithms, and Applications). Prentice-Hall, Upper Saddle River, New-Jersey. 461p. 
Folgmann, A.B., S. Wenzel, R. Roscher, B. Uebbing. 2017. Sea Level Anomaly Prediction Using Recurrent Neural Networks. arXiv:1710.07099v1. Institute of Geodesy and Geoinformation, University of Bonn, Bonn.

Ginanjar, S., C.K. Putri, R. Nurhakim. 2019. Kajian Kenaikan Muka Air Laut dan Tinggi Genangan (Rob) Pada Tahun 2023, 2028, dan 2033 di Kota Saumlaki, Kabupaten Maluku Tenggara Barat. Jurnal Meteorologi Klimatologi dan Geofisika, 6(2): 39-48.

Idris. 2002. Model Numerik Tiga Dimensi Barotropik Arlindo di Perairan Indonesia dan Sekitarnya. [Tesis]. Departemen GM, ITB.

IPCC. 2007. Climate Ghange Impact, Adaptation and Vulnerabilty. Cambridge University Press Cambridge, United Kingdom, 1000p.

Jumarang, M.I. dan N.S. Ningsih. 2013. Transpor Volume Massa Air di Selat Sunda Akibat Interaksi Enso, Monsun dan Dipole Mode. Dalam: Prosiding Semirata FMIPA Universitas Lampung, 2013: 409-415.

Khasanah, U.N. dan I.M. Marza. 2017. Analisis Kenaikan Muka Air Laut Menggunakan Data Altimetri untuk Aplikasi Mitigasi Perubahan Iklim di Wilayah Pengelolaan Perikanan (WPP) 573. Dalam: Seminar Penginderaan Jauh Ke-4 Tahun 2017.

Khasanah I.U., S. Wirdinata, Q. Guvil. 2017. Analisis Harmonik Pasang Surut untuk Menghitung Nilai Muka Surutan Peta (Chart Datum) Stasiun Pasut Sibolga. Dalam: Prosiding Seminar Nasional Strategi Pembangunan Infrastruktur ke-3 (SPI-3). ITP, Padang.

Kismawardhani, R., A. Wirastriya dan D. Berlianty. 2018. Sea Level Rise in The Java Sea Based on Altimetry Satellites Data Over 1993-2015. In: IOP Conference Series: Earth And Environmental Science, 165, 012006.

Levermann, A., P. Clark, B. Marzeion, G. Milne, D. Pollard, V. Radic, A. Robinson. 2013. The multimillennial sea-level commitment of global warming. In: Proceedings of the National Academy of Sciences, 110(34): 13745-13750.

Maharani, W. 2009. Klasifikasi Data Menggunakan JST Backpropagation Momentum dengan Adaptive Learning Rate. Dalam: Semin. Nas. Inform., Vol 1 no.semnasIF: 25-31.

Marpaung, S. dan W.K. Harsanugraha. 2014. Karakteristik Sebaran Anomali Tinggi Muka Laut Di Perairan Bagian Selatan dan Utara Pulau Jawa. Dalam: Seminar Nasional Penginderaan Jauh 2014.

Nababan, B. 2015 Dinamika Anomali Paras Laut Perairan Indonesia. Journal Ilmu Kelautan and Teknologi Kelautan Tropis, 7(1): 259-272.

Nabilah, F., Y. Prasetyo, A. Sukmono. 2017. Analisis Pengaruh Fenomena El Nino dan La Nina terhadap Curah Hujan Tahun 1998-2016 Menggunakan Indikator ONI (Oceanic Nino Index) (Studi Kasus : Provinsi Jawa Barat). Jurnal Geodesi Undip, 6(4): 402-412.

Oktaviani, N.A., M.I. Jumarang, A. Ihwan. 2014. Kajian Elevasi Muka Air Laut di Perairan Indonesia Pada Kondisi El Nino dan La Nina. Prisma Fisika, 2(1): 06-10.

Rahmstorf, S., G. Foster, A. Cazenave. 2012. Comparing climate projections to observations up to 2011. Enviromental Research Letters, 7(4), 5pp.

Sofian, I. 2007. Simulation of The java Sea using an Oceanic Feneral Circulation Model. J. Geomatika, 13(2): 1-14.

Susanto, K.E., M.A. Marfai, D. Mardianto. 2010. Proyeksi Kenaikan Permukaan Laut dan Dampaknya Terhadap Banjir Genangan Kawasan Pesisir. Majalah Geografi Indonesia, 24(2): 101-120.

Strassburg, M.W., B.D. Hamlington, R.R. Leben, P. Manurung, J.L. Gaol, B. Nababan, S. Vignudelli, and K.Y. Kim. 2015. Sea level trends in Southeast Asian seas. Clim. Past, 11: 743-750.

Wenzel, M. And J. Schröter. 2010. Reconstruction of Regional Mean Sea Level Anomalies From Tide Gauges Using Neural Networks. Journal of Geophysical Research, 115(C8): 1-15.

Wuriatmo, Hastho. 2012. Analisa Sea Level dari Data Satelit Altimetri Topex/Poseidon, Jason-1 dan Jason-2 di Perairan Laut Pulau Jawa Periode 2000-2010. Indonesian Journal of Applied Physics, 2(7): 65-72.

Wyrtki, K. 1961. Physical oceanography of the Southeast Asian waters. Naga Report 2, Scripps Institution of Oceanography, La Jolla, CA, 195pp. 